\title{
THE RULE OF LAW AND THE INEVITABILITY OF DISCRETION
}

\author{
PETER M. SHANE*
}

At least two things are implicit in the title to this panel, "The Rule of Law and the Administrative State": first, there is something we can agree on called the Rule of Law; second, this Rule of Law is compromised in practice because of the advent of the Administrative State. The first of these propositions needs significant elaboration, and the second is wrong.

There are deep disagreements about what the Rule of Law is. ${ }^{1}$ At the most general level, to have a "Rule of Law" presumably means that those who govern us cannot wield the power of the state towards their personal ends either "just because they want to ... or because they have force on their side." 2 What that entails, however, has eluded precise definition for centuries. ${ }^{3}$ The Rule of Law, to use a phrase that Jeremy Waldron borrowed from the philosopher W. B. Gallie, is "an essentially contested concept." 4 "Essentially contested" does not just mean "very hotly contested." 5 It means that there is robust dispute as to the very core of

\footnotetext{
* Jacob E. Davis and the Jacob E. Davis II Chair in Law, The Ohio State University Moritz College of Law. This essay was adapted from panel remarks on "The Rule of Law and the Administrative State," given at the 2012 Federalist Society Annual Student Symposium held March 2, 2012, at Stanford Law School in Palo Alto, California.

1. Compare Jeremy Waldron, Jr., The Concept and the Rule of Law, 43 GA. L. REV. 1, 6-8 (2008) (arguing for an understanding of the Rule of Law that emphasizes predictability and the procedural aspects of law practice), with Richard H. Fallon, "The Rule of Law" as a Concept in Constitutional Discourse, 97 COLUM. L. REV. 1, 6 (1997) (proposing a conception of the Rule of Law as "comprising multiple strands" including the historicist, formalist, proceduralist, and substantive definitions of the Rule of Law).

2. Peter M. Shane, Madison's Nightmare: How Executive Power ThreatENS AMERICAN DEMOCRACY 115 (2009).

3. See Jeremy Waldron, Is the Rule of Law an Essentially Contested Concept (in Florida)?, 21 LAW \& PHIL. 137, 140-44 (2002) (surveying the history of dispute surrounding the concept of the "Rule of Law").

4. Id. at 148 (citing W.B. Gallie, Essentially Contested Concepts, 56 PROC. ARISTOTELIAN SOC'Y 167-69 (1956)).

5. Id. at 149 (internal quotation marks omitted).
} 
the concept. ${ }^{6}$ The internal complexity of the concept-the many features it comprises-gives rise to rival versions of the concept that prioritize those features very differently.

Professor Richard Epstein advances a version of the Rule of Law that is characterized by the constraint of government discretion through the promulgation of general rules, which are predictable in their application and susceptible to fairly straightforward judicial enforcement. ${ }^{8}$ In Professor Epstein's view, the administrative state compromises this version of the Rule of Law because it tolerates broad delegations of lawmaking authority to administrative agencies. ${ }^{9}$ He observes that the statutes that empower federal agencies embody limitations on agency discretion that are somewhere between porous and evanescent. ${ }^{10} \mathrm{He}$ argues that the steps agencies take in implementing these statutes lack the generality and predictability appropriate for law. ${ }^{11}$

The key problem with this indictment is that it overdraws the distinction between the amount of problematic discretion afoot in the administrative state and what would be the case in what might be called the "classical liberal state." Congress, as the primary lawmaking body in the liberal state, would still be vested with enormous discretion by the terms of Article I of the Constitution. ${ }^{12}$ Anyone who thinks Congress is less prone than agencies to favoritism, rent-seeking, or departures from generality, simply is not paying atten-

\footnotetext{
6. Id.

7. See id. at 140-43 (contrasting, among others, Antonin Scalia, The Rule of Law as a Law of Rules, 56 U. CHI. L. REV. 1175, 1182 (1989); Lawrence B. Solum, Equity and the Rule of Law, in NOMOS XXXVI: THE RULE OF LAW 120 (Ian Shapiro ed., 1994); and Ernest Weinrib, The Intelligibility of The Rule of Law, in THE RULE OF LAW: IDEAL OR IDEOLOGY 59, 63 (Allan C. Hutchinson \& Patrick Monahan eds., 1987)).

8. See Richard A. Epstein, Government by Waiver, 7 NAT'L AFF. 39, 39 (2011). ("The rule of law requires that all disputes ... be tried before neutral judges, under rules that are known and articulated in advance. Every party must have notice of the charge against him and an opportunity to be heard in response; each governing rule must be consistent with all the others, so that no person is forced to violate one legal requirement in order to satisfy a second."); see also Richard Epstein, The Perilous Position of the Rule of Law and the Administrative State, 36 HARV. J.L. \& PUB. POL'Y 5 (2013).

9. See Richard A. Epstein, Why the Modern Administrative State is Inconsistent with the Rule of Law, 3 N.Y.U. J.L. \& LIBERTY 491, 503-04 (2008).

10. See Epstein, Government by Waiver, supra note 8, at 45-46.

11. See id. at 40.

12. See U.S. CONST. art. I, $\S 8$.
} 
tion. ${ }^{13}$ Additionally, courts, no less than agencies, are susceptible to unpredictable, ideologically driven decisionmaking and manipulation by rent-seeking parties in litigation. ${ }^{14}$ Discretion will simply not go away.

The challenge for those of us who believe in a Rule of Law, therefore, is not to blink at the inevitability of discretion or resign "Rule of Law" to the dustbin of empty slogans. The task is to articulate a compelling conception of the Rule of Law-a conception that is well-suited to the inevitability of discretion in the administrative state. That discretion is rooted in two realities: "One is that public officials, even if conscientiously attentive to law, will often find the written law applicable to their particular problems or opportunities to be genuinely vague." ${ }^{15}$ "The second ... is that, with regard to a great deal-perhaps mostgovernment activity, the chances are remote that law can and will be enforced against nonconforming behavior."16 Our Rule of Law conception must have operational consequence even when the actual prospects of sanction for illegality are remote.

Approached in this way, what is important about law as "law" - whether embodied for the executive branch in judicial opinions, statutes enacted by Congress, or the sometime Delphic phrases of the Constitution-is that law embodies the plans and purposes of voices not immediately present, but which have authority to bind the future. To borrow Jeremy Waldron's elegant formulation of a position he ascribes to Ronald Dworkin, the Rule of Law should be understood as the "ascendancy" in our constitutional system "of a certain culture of argumentation" or interpretation. ${ }^{17}$ Within this culture

the Rule of Law consists in issues being settled by ... legal processes, procedures of deliberation and reason-giving that are focused on antecedent legal materials rather than political advantage, and in a form of deference on the part of the contesting parties that is motivated by the stake they have,

13. See, e.g., William N. Eskridge, Jr., Politics Without Romance: Implications of Public Choice Theory For Statutory Interpretation, 74 VA. L. REV. 275, 285 (1988); John O. McGinnis, The Original Constitution and its Decline: A Public Choice Perspective, 21 HARV. J.L. \& PUB. POL'Y 195, 200-01 (1997).

14. See Waldron, supra note 3, at 147; see also Arthur D. Hellman, Precedent, Predictability, and Federal Appellate Structure, 60 U. PITT. L. REV. 1029, 1032-33 (1999).

15. SHANE, supra note 2, at 115.

16. Id.

17. See Waldron, supra note 3, at 156. 
along with their fellow citizens, in the integrity of the legal and constitutional order. ${ }^{18}$

Under this conception of the Rule of Law, a critical function of the law in operation is to make manifest a range of interests and concerns that might not otherwise be vigorously articulated, much less treated as binding, when key decisions are made. ${ }^{19}$ Attending to these voices through professionally recognized forms of interpretation is a critical way in which government officials and their lawyers breathe life into the Rule of Law. ${ }^{20}$

If this account is appealing, then the key ingredients of the Rule of Law are not to be found in the abstract properties of legal rules. Instead, they are to be found in the institutional arrangements that foster a Rule of Law culture. Some of these are formal interbranch institutions, such as judicial review. ${ }^{21}$ Others are formal organizational arrangements within the executive branch, such as the practice of rendering formal Attorney General opinions or the organization of general counsel offices to avoid their policy capture by individual programs within executive agencies. The quality of executive branch lawyering is also just as critical as any other institution supporting a Rule of Law culture.22 When executive branch lawyers attend to statutes, judicial opinions, the dictates of the Constitution, and prior opinions of the executive branch itself, they bring to bear the multiple authoritative voices of earlier times who themselves had to reach consensus in order to create binding norms. How lawyers perform that function helps to determine the vitality of law as a buffer against the more immediate passions of partisanship or the undisciplined pursuit of self-interest. ${ }^{23}$

As I wrote in my 2009 book, Madison's Nightmare, for such an account of the Rule of Law to be plausible, "the written documents of law must be buttressed by a set of norms, conventional expectations, and routine behaviors that lead officials to behave as if they are accountable to the public interest and to legitimate sources of legal and political authority." ${ }^{24}$ In a

18. Id. at 147.

19. SHANE, supra note 2 , at 12 .

20. See Waldron, supra note 3 , at $146-47$.

21. See Russell R. Wheeler \& Robert A. Katzmann, A Primer on Interbranch Relations, 95 GEO. L.J. 1155, 1157 (2007).

22. See SHANE, supra note 2, at 11-12.

23. See id.

24. SHANE, supra note 2, at 116. 
checks-and-balances system, norms, cooperative arrangements, and informal coordination activities are at least as important as the formal rules themselves. ${ }^{25}$ Under this institutional conception of the Rule of Law, to quote Justice Felix Frankfurter, "the relevant question is not, has it been achieved, but, is it conscientiously and systematically pursued." 26

If this conception is appealing, then it ought to be noted immediately that the Rule of Law arrangements surrounding administrative policymaking in the United States are far better suited to the Rule of Law than the arrangements surrounding Congress. ${ }^{27}$ To take but one example, Congress recently decided, as part of the Middle Class Tax Relief and Job Creation Act of 2012, that the Federal Communications Commission (FCC) could move to make more of our radio spectrum available for broadband by inducing television broadcasters, through the use of auctions, to give up portions of their spectrum allocation that they no longer regard as having great economic value. ${ }^{28}$ Among the many policy decisions implicit in the Act were a determination to make broadcaster participation in these auctions voluntary, and a determination to make little provision for the set-aside of unlicensed spectrum-spectrum that users share, without consulting the FCC, to operate cordless phones, microwave ovens, garage door openers, and numerous other devices. ${ }^{29} \mathrm{WiFi}$ is the most important technology

25. See id.

26. Felix Frankfurter, John Marshall and the Judicial Function, 69 HARV. L. REV. 217, 235 (1955).

27. Congress, for example, is not legally required to provide any contemporaneous public justification for its legislative enactments, which the judiciary must nonetheless uphold, in the ordinary case, if any set of facts may be hypothesized to a court as providing a rational basis for those enactments. By way of contrast, significant agency actions are typically tested against a record that the agency is legally compelled to assemble in order to demonstrate that its actions were, when taken, legally grounded, soundly reasoned, and based on evidence. Thus, the Supreme Court has said in a famous rulemaking case: "The Department of Transportation suggests that the arbitrary and capricious standard requires no more than the minimum rationality a statute must bear in order to withstand analysis under the Due Process Clause. We do not view as equivalent the presumption of constitutionality afforded legislation drafted by Congress and the presumption of regularity afforded an agency in fulfilling its statutory mandate." Motor Vehicle Mfrs. Ass'n of U.S., Inc. v. State Farm Mut. Auto. Ins. Co., 463 U.S. 29, 43 n.9 (1983).

28. Middle Class Tax Relief and Job Creation Act of 2012, Pub. L. No. 112-96, $\S \S 6401-6402,126$ Stat. 156, 222-30 (2012).

29. See Paul R. Milgrom, Jonathan Levin \& Assaf Eilat, The Case for Unlicensed Spectrum 6 (Oct. 12, 2011), available at http://papers.ssrn.com/sol3/papers.cfm? abstract_id=1948257. 
that relies on unlicensed spectrum. ${ }^{30}$ It carries, for example, about ninety percent of iPad and all other tablet data. ${ }^{31}$ Congress's policy choices are thus of enormous (and negative) consequence, but Congress is under no enforceable constraint to justify them. ${ }^{32}$ There is no plausible legal challenge to the unwarranted protection that results from this law for both incumbent broadcasters and incumbent cell phone companies.

Imagine now, if you will, that the very same choices were embodied in an FCC regulation. The FCC would be required to demonstrate, based on an administrative record, that its choices were predicated on a permissible reading of its authorizing statute, sound fact-finding, and a reasoned analysis connecting the facts to the law. ${ }^{33}$ The agency's determinations could be set aside if the public had been insufficiently warned of the contemplated action, or if the explanation for the FCC's actions failed to take into account significant issues raised to the agency's attention during a notice-and-comment period. ${ }^{34}$ Amazon.com, for example, whose growth significantly depends on unlicensed spectrum, would have a much greater chance of invoking the law to good effect in a challenge to the FCC than a challenge to Congress. This is so even though it is hard to imagine an agency operating under a broader delegation than does the FCC. ${ }^{35}$

The real challenges to my conception of the Rule of Law in contemporary America come not in the operation of the everyday regulatory bureaucracy, but at the edges of separation-of-

30. See id. at 1 .

31. See Chetan Sharma, US Wireless Market Update: Q4 2011 and Full Year 2011, at 7, Mar. 19, 2012, http://www.chetansharma.com/USmarketupdate2011.htm (last visited Nov. 20, 2012).

32. Because the Act mandates no particular private behavior and deprives no one of property or any other colorable constitutional interest, it is doubtful any citizen could show an injury sufficient to ground Article III standing to challenge the congressional scheme. See Allen v. Wright, 468 U.S. 737, 751 (1984). Even if private parties could show that Congress's decision not to set aside additional unlicensed spectrum disappointed their economic expectations, the law amounts to a conventional sort of economic regulation that would trigger no more than minimal scrutiny. Williamson v. Lee Optical, 348 U.S. 483, 489-91 (1955).

33. See Hispanic Info. \& Telecomms. Network, Inc. v. FCC, 865 F.2d 1289, 129798 (D.C. Cir. 1989) (holding that "modicum of reasoned analysis" was required in order to uphold FCC action).

34. See Am. Radio Relay League, Inc. v. FCC, 524 F.3d 227, 236-38, 242 (D.C. Cir. 2008) (upholding challenge to FCC rulemaking based on FCC's failure to adequately comply with notice-and-comment procedure).

35. See Hispanic Info., 865 F.2d at 1297-98. 
powers law-where it falls, in particular, to our elected branches, working within the famously vague commands of the Constitution, to pursue their political objectives aggressively while attending to the overall "integrity of the legal and constitutional order." 36 To illustrate this point, consider a thought experiment based on recent events. Imagine that Congress, in the late summer of 2011, had simply refused to raise the U.S. debt ceiling. Without authority to borrow funds sufficient to cover current expenditures, the President could not have continued to spend all the money Congress had already appropriated unless he were prepared to have the U.S. default on its debts. ${ }^{37} \mathrm{He}$ would have had before him only two legal avenues, both drastic and unprecedented. He could have asserted authority under the Budget and Impoundment Control Act of 1974 to withhold appropriated funds from expenditure. ${ }^{38}$ Alternatively, he could have declared that he was obligated under the Fourteenth Amendment to secure financing for the public debt, notwithstanding the statutory debt limit. ${ }^{39}$ The latter would have been the far more creative stance from the standpoint of legal interpretation. It is hard to see who could have challenged it in court. In a way, though, it would have been a less aggressive stance in terms of displacing congressionally enacted law. If President Obama had tried to keep us solvent by deferring spending, he would have had to make a host of unilateral policy decisions as to how much spending to postpone and where, notwithstanding the levels of spending

36. See Waldron, supra note 3 , at 147.

37. See Michael Cooper \& Louise Story, Q. and A. on the Debt Ceiling, N.Y. TIMES, July 27, 2011, http://www.nytimes.com/2011/07/28/us/politics/28default.html?page wanted=all\&_r=0.

38. In "budget-speak," such withholding would be called a "deferral," and could last until the end of the relevant fiscal year. The Budget and Impoundment Control Act permits such deferrals in order "to provide for contingencies." 2 U.S.C. § 684(b). Within forty-five days of the end of the deferral period, the President could propose to Congress that it permanently rescind the obligation to spend those funds, the expenditure of which he had deferred. 2 U.S.C. § 683. Although Congress could technically decline to go along, it would obviously be embarrassing for Congress to demand simultaneously that the President not borrow additional funds and spend money that, effectively, does not exist.

39. Though President Obama publicly refused to discuss such measures, constitutional scholars were divided over whether it was a legitimate option. See Zachary A. Goldfarb, Obama, Democrats not ready to play 14th Amendment card with debt ceiling, WASH. POST, July 6, 2011, http://www.washingtonpost.com/business/ economy/obama-democrats-not-ready-to-play-14th-amendment-card-with-debtceiling/2011/07/06/gIQAVU1O1H_story.html. 
Congress had already directed. On the other hand, had he continued borrowing funds to cover government expenditures, he would have defied the debt limit statute, but upheld the rest of Congress's enacted appropriations laws.

The Rule of Law, in such a situation, does not prescribe a determinate course. It would be quite understandable if considerations other than the Rule of Law at least shared priority in the President's decision making. Whatever the President's choice, he could have explained it to the country in rhetoric formally consistent with the Rule of Law, but the catastrophic economic implications of default would presumably-and perhaps legitimately-have dominated the Administration's thinking. Thus, it must be acknowledged that a government in which the "Rule of Law" is "conscientiously and systematically pursued" may, on rare and genuinely extraordinary occasions, still be a government in which other virtues take occasional priority. ${ }^{40}$ We want the Rule of Law-but perhaps not only the Rule of Law. This is a proposition I would not wish to see the executive branch pursue with any regularity, but its importance signals that the real dangers faced by the Rule of Law are inherent, not only in the administrative state, but in government itself. If the Rule of Law seems more precarious in 2012 than we imagine it to have been in earlier times, this is not because new forms of administration have emerged. It is because social forces in tension with, or antagonistic to, the Rule of Law culture-think "partisanship," or "media" - have risen in ascendancy.$^{41}$ Our panel might better have been called, "The Rule of Law and the Polarized State."

40. Frankfurter, supra note 26, at 235.

41. See Jennifer Steinhauer, Weighing the Effect of an Exit of Centrists, N.Y. TIMES, Oct. 8, 2012, http://www.nytimes.com/2012/10/09/us/politics/pool-of-moderatesin-congress-is-shrinking.html?pagewanted=all. 